\title{
PENATAAN LINGKUNGAN SEBAGAI INSTRUMEN PENCEGAHAN KEJAHATAN SEKSUAL TERHADAP ANAK STUDI KASUS KOTA BANDAR LAMPUNG
}

\author{
Asirin \\ Perencanaan Wilayah dan Kota, Institut Teknologi Sumatera (ITERA) \\ Email: asirin@itera.ac.id \\ Lianita Zanith \\ Sekolah Alam Lampung
}

\begin{abstract}
The incidence of sexual crimes against children occurs in many areas of Bandar Lampung Municipality. This study aims to explore the condition and the lack of environmental arrangement in Bandar Lampung Municipality, in order to build a safe environment that can prevent sexual crimes in children. The study limits the scope of the material using the mainframe conceptual framework of neighborhood planning (neighborhood planning) and interventions for safe environmen- tal arrangement for children's lessons from Tokyo Municipality, Japan. This research uses qualitative methods of analysis and verification effort (reliability and validity). The results show that Bandar Lampung City has not implemented a wellplanned environmental plan for the safety of children from crime. The solving of child crimes in Bandar Lampung City is still reactive in tackling criminal cases, not preventive by organizing the residential, school, and other public spaces in a well planned and well managed by the municipal government by involving the surrounding community.
\end{abstract}

Keywords: Child; Environmental arrangement; Public space; Security; Sexual crime.

\begin{abstract}
ABSTRAK
Kejadian tindak kejahatan seksual terhadap anak banyak terjadi di wilayah Kota Bandar Lampung. Penelitian ini bertujuan untuk menggali kondisi dan kekurangan penataan lingkungan di Kota Bandar Lampung, dalam rangka membangun lingkungan yang aman yang dapat mencegah kejahatan seksual pada anak. Penelitian ini membatasi pada ruang lingkup materi dengan menggunakan kerangka konsep utama penataan lingkungan (neighborhood planning) dan intervensi-intervensi untuk penataan lingkungan aman bagi anak pelajaran dari Kota Tokyo, Jepang. Penelitian menggunakan metode analisis dan upaya verifikasi (reliabilitas dan validitas) kualitatif. Hasil penelitian menunjukkan bahwa Kota Bandar Lampung belum menerapkan tata lingkungan yang terencana dengan baik untuk keselamatan anak dari kejahatan. Penanganan kejahatan anak di Kota Bandar Lampung masih bersifat reaktif menanggulangi kasus kejahatan, belum bersifat mencegah dengan menata lingkungan perumahan, sekolah, dan ruang publik lainnya secara terencana dan terkelola dengan baik oleh pemerintah kota dengan melibatkan masyarakat di sekitarnya.
\end{abstract}

Kata Kunci: Anak; Keamanan; Kejahatan seksual; Penataan lingkungan; Ruang publik 


\section{PENGANTAR}

Kejadian tindak kejahatan seksual terhadap anak banyak terjadi di perkotaan dan perdesaan di berbagai negara (lihat di Lalor, 2004; Finkelhor dkk., 2009), termasuk di Kota Bandar Lampung, Indonesia. Pusat Data dan Informasi Komisi Nasional Perlindungan Anak (2015) menyatakan bahwa selama periode 20102014, ada sekitar 21.689.797 kasus pelanggaran hak anak yang tersebar di 34 provinsi dan 179 kabupaten/kota di Indonesia, sebanyak 58\% merupakan kejahatan seksual dan $42 \%$ adalah kasus kekerasan fisik, penculikan, eksploitasi ekonomi, dan perdagangan anak. Dengan fakta tersebut, Komisi Nasional Perlindungan Anak (2014) pernah menyatakan bahwa Indonesia darurat kekerasan terhadap anak, termasuk kekerasan seksual. Gambaran rinci kekerasan terhadap anak, termasuk kekerasan seksual pada anak di Indonesia, telah diuraikan oleh Suharto (2015). Pada konteks wilayah Provinsi Lampung, tahun 2016 tercatat 21 peristiwa kejahatan seksual terhadap anak dengan korban 49 Anak. Dari 49 anak korban kejahatan seksual tersebut sebanyak 2 anak meninggal dunia (Lembaga Advokasi Anak/LAdA-Damar, 2016). Sementara itu, di Kota Bandar Lampung, selama periode Januari hingga Mei 2016, Polisi Resort Kota (Polresta) Bandar Lampung sudah menangani 28 kasus kejahatan seksual terhadap anak. Pelaku kekerasan terhadap anak tersebut biasanya didominasi oleh orang-orang terdekat yang sudah mengenal korban (Suharto, 2015; Sampson dkk., 1997). Beberapa pelaku biasanya juga adalah homoseksual (Jenny dkk., 1994).

Kejahatan seksual adalah suatu bentuk pelecehan seksual oleh orang dewasa atau yang lebih tua, yang memiliki posisi kekuatan dan kendali lebih terhadap anak, menggunakan anak-anak sebagai stimulasi seksual (APA, 2013). Kejahaatan seksual terhadap anak di ruang publik merupakan tindakan secara langsung maupun kejahatan seksual sebagai tindakan lanjutan dari tindak kejahatan lainnya yang dilakukan terlebih dahulu di ruang publik, seperti penculikan. Ruang publik lingkungan adalah lingkungan taman bermain atau taman, lingkungan permukiman, dan lingkungan sekolah.
Isu tata kota yang perlu menciptakan keamanan untuk masyarakatnya merupakan agenda kekinian yang dibahas di tingkat internasional dan nasional. Sustainable Development Goals (SDGs) 2015-2035, pada target Nomor 11 menyatakan bahwa pembangunan kota-kota di dunia termasuk di Indonesia harus mencapai kota yang aman (save), inklusif (inclusive), tangguh (resilient), dan berkelanjutan (sustainable). Selain itu, terdapat agenda baru pembangunan kota (New Urban Agenda) UN HABITAT mengagendakan bahwa kondisi lingkungan yang aman, sehat, inklusif bagi anak harus terwujud di dalam kota dan di lingkungan permukiman. UN HABITAT, termasuk Indonesia sebagai anggotanya, juga berkomitmen memprioritaskan upaya-upaya peningkatan kesehatan dan keamanan setiap anak-anak menuju sekolah. Di Indonesia, lingkungan kota yang aman merupakan amanat dari Undang-Undang No. 26 Tahun 2007 tentang Penataan Ruang. Di dalam Undang-Undang tersebut disebutkan bahwa tujuan penataan ruang salah satunya adalah untuk mewujudkan tata ruang yang aman, nyaman, produktif, dan berkelanjutan. Kebijakan pembangunan kota di Indonesia juga mengamanatkan pembangunan Kota Layak Anak (KLA) (lihat Widiyanto dan Rijanta, 2012).

Kejahatan seksual terhadap anak merupakan masalah kompleks yang perlu melibatkan banyak disiplin ilmu yang metode penanganannya perlu terus dikembangkan (lihat juga Renk dkk., 2002). Pada konteks lingkungan untuk anak, keamanan merupakan suatu konsep yang kompleks dan dapat memasukkan komponen yang beragam seperti bahaya dari pihak yang tidak dikenal, kecelakaan personal, keamanan jalan dan intimidasi (Carver, 2008). Mulroy (1997) dan Mulroy dan Shay (1997) menyarankan perlunya kolaborasi antar organisasi baik pembuat kebijakan, organisasi non profit, dan pekerja sosial dalam praktik dan pengembangan inovasi dalam menangani kejahatan terhadap anak dan pengembangan inovasi program penanganan. Bahkan, penataan lingkungan dalam prosesnya perlu melibatkan anak seperti yang disarankan 
oleh Sutton dan Kemp (2002) dan Loebach dan Gilliland (2010). Salah satu keilmuan yang penting dapat memberikan solusi pencegahan kejahatan seksual yaitu ilmu perencanaan kota, sub bidang penataan lingkungan (neighborhood planning). Penataan lingkungan bertujuan untuk mengatasi masalah-masalah besar yang dihadapi suatu kota, salah satunya adalah masalah kriminalitas (Rohe, 2009).

Pada tingkat yang paling mendasar, penataan lingkungan melibatkan publik, organisasi non profit, dan usaha-usaha pihak swasta dalam merencana yang fokus pada karakter fisik satu atau lebih lingkungan, namun itu didefinisikan pada tingkat lokal (Rohe, 2009). Penataan lingkungan didefinisikan suatu kegiatan mendesain lingkungan baru atau mendesain pembangunan kembali (revitalisasi) lingkungan yang lama (Rohe, 2009). Sementara itu, Checkoway (1985) mendefinisikan penataan lingkungan tidak hanya pengembangan fisik tetapi juga pengembangan layanan sosial pada tingkat lingkungan. Checkoway (1985) menyatakan bahwa penataan lingkungan adalah suatu proses masyarakat mengembangkan rencana, program, atau layanan sosial pada tingkat lingkungan ketetanggan (neighborhood).

Penelitian yang secara umum menggunakan pendekatan intervensi sosial atau ekologi pembangunan (ecological development) dalam penanganan kejahatan seksual telah dilakukan oleh Hay dan Jones (1994), Earls dan McGuire (1994), Sabol dkk., (2004), serta Daro dan McCurdy (2007). Penelitian Hay dan Jones (1994) yang menggunakan kerangka ekologi pembangunan menunjukkan bahwa dalam menangani masalah kejahatan terhadap anak, baik pada faktor risiko dan faktor perlindungan, memerlukan intervensi sosial pada tingkat individu, keluarga, komunitas dan lingkungan, budaya, dan masyarakat yang lebih luas.

Penelitian pada topik penataan lingkungan secara umum banyak dilakukan di Indonesia salah satunya oleh oleh Yunianto (2016) yang berfokus pada analisis penyediaan dan desain RTH yang mempertimbangkan pola aktivitas dan fungsi RTH untuk terciptanya RTH publik berbasis green design. Namun, kajian Yunianto (2016) belum fokus desain RTH yang aman bagi anak dari tindak kejahatan. Adapun penelitian spesifik pada tata lingkungan untuk keamanan anak sudah dilakukan oleh Drianda dkk., (2014) namun hanya mengambil pelajaran langsung dari Kota Tokyo Jepang, tanpa menggali kondisi dan dan potensi di Indonesia.

Menurut Drianda, dkk. (2015) Jepang telah melakukan penataan lingkungan kota yang aman untuk anak. Upaya-upaya penataan lingkungan di Kota Tokyo di Jepang menurut Drianda, dkk. (2015) antara lain (1) peningkatan aksi komunitas untuk pencegahan potensi tindak kriminal; (2) penggunaan teknologi untuk pencegahan tindak potensi kriminal; dan (3) desain dan manajemen ruang kota. Penelitian Drianda, dkk. (2015) itu memiliki keterbatasan yaitu terbatas hanya memperlihatkan kondisi penataan lingkungan yang aman untuk anak di Kota Tokyo, Jepang. Drianda, dkk. (2015) mengasumsikan bahwa di Indonesia belum ada sama sekali upaya intervensi tata lingkungan. Drianda, dkk. (2015) belum melihat konteks kondisi dan potensi kota di Indonesia. Terdapat partisipasi warga dalam proses perencanaan pembangunan, bahkan Tallo dan Paramita (2015) menunjukkan ada pembangunan dari partisipasi masyarakat tanpa campur tangan pemerintah.

Dengan kata lain, Drianda, dkk (2015) belum secara operasional melakukan penyesuaian-penyesuain dalam konteks kota di Indonesia. Dengan demikian penelitian tersebut perlu ditindaklanjuti dengan penelitian ini. Sesungguhnya kota-kota di Indonesia bisa jadi sudah ada beberapa upaya-upaya penataan lingkungan yang aman terhadap anak. Dengan begitu, penelitian yang diperlukan adalah analisis kekurangannya (gap analysis) dan bagaimana potensi-potensi yang ada di Kota Bandar Lampung itu ditingkatkan menjadi suatu modal yang dilibatkan dalam penataan lingkungan yang mampu mencegah kejahatan terhadap anak. Dengan adanya latar belakang persoalan tersebut, penelitian ini bertujuan untuk menggali kekurangan penataan lingkungan di Indonesia dengan studi kasus Kota Bandar Lampung dalam 
rangka membangun lingkungan aman yang dapat mencegah kejahatan seksual pada anak. Selanjutnya, diambil tindakan penyesuaian dari kerangka intervensi-intervensi hasil pelajaran contoh paling baik (best practice) dari penataan lingkungan di Kota Tokyo di Jepang.

Manfaat penelitian ini secara empiris yaitu memberikan gambaran kondisi kekurangan penataan lingkungan dan penyediaan sarana prasarana untuk keamanan anak di Kota Bandar Lampung, sebagai masukkan untuk perbaikan pedoman tata lingkungan kota. Penelitian ini dapat berguna sebagai masukkan juga bagi perencana kota dan pemerintah kota merencana lingkungan kotanya, agar merancang kota dengan mempertimbangkan aspek keselamatan anak dari tindak kejahatan. Adapun secara teoritis penelitian ini dapat bermanfaat dalam mengembangkan konsep kota ramah anak pada tingkat lingkungan dengan konteks negara berkembang.

Penelitian ini membatasi pada ruang lingkup materi dengan menggunakan kerangka konsep utama antara lain penataan lingkungan (neighborhood planning) dan intervensiintervensi untuk penataan lingkungan aman bagi anak pelajaran dari Kota Tokyo, Jepang.

Penelitian ini mengumpulkan data primer dengan wawancara dan observasi kondisi lingkungan perumahan, tempat bermain, taman kota, sekolah, pasar, terminal, dan stasiun di Kota Bandar Lampung. Penelitian ini mewawancarai perwakilan pihak-pihak terkait dari Dinas Pendidikan Kota Bandar Lampung, Yayasan Sekolah Alam Lampung (tingkat Pendidikan Anak Usia Dini (PAUD, Sekolah Dasar (SD), Sekolah Menengah Pertama (SMP), dan Sekolah Menengah Atas (SMA)), Polres Kota Bandar Lampung dan Polsek Sukarame, Dinas Perhubungan Kota Bandar Lampung, Dinas Pekerjaan Umum Kota Bandar Lampung, Pengamat Tata Bangunan dan Lingkungan, Bidang Perlindungan Perempuan dan Anak Badan Pemberdayaan Perempuan dan Perlindungan Anak Provinsi Lampung, Lembaga Advokasi Anak (LAdA) dan Lembaga Advokasi Perempuan Damar di Provinsi Lampung. Penelitian ini mengumpulan data sekunder dilakukan dengan mengumpulkan data profil kejahatan seksual terhadap anak, pendidikan dan upaya-upaya komunitas dalam mencegah kejahatan seksual anak. Penelitian ini juga mengumpulkan data sekunder peraturan terkait tata lingkungan yang berlaku di Kota Bandar Lampung. Penelitian ini juga mengumpulkan data sekunder terkait kondisi tata lingkungan di Kota Tokyo di Jepang yang berasal dari artikel ilmiah karya Drianda dkk., (2009).

\section{PEMBAHASAN \\ Analisis dan Verifikasi}

Penelitian ini melakukan metode analisis dan upaya verifikasi (reliabilitas dan validitas) kualitatif yang disarankan Yin (2009). Proses analisis pada penelitian ini meliputi (1) menyiapkan transkripsi, catatan observasi, foto, dokumen data sekunder; (2) mengolah dan mempersiapkan data untuk dianalisis; (3) membaca keseluruhan data; (4) melakukan open coding data; (5) membuat tema-tema dan deskripsi-deskripsi dari tema-tema tersebut kemudian diinterpretasi secara naratif; (6) dan merumuskan kesimpulan dan rekomendasi. Kesimpulan dan rekomendasi dilakukan dengan memaknai kasus. Pemaknaan kasus tersebut didapat dari membaca keseluruhan fakta dan bukti-bukti kasus secara berulangulang kemudian mendiskusikannya dengan rekan peneliti. Adapun upaya verifikasi (reliabilitas dan validitas) kualitatif meliputi mendokumentasikan prosedur penelitian; membuat protokol dan database studi kasus; triangulasi; deskripsi yang kaya dan padat; dan bertanya jawab dengan rekan peneliti di Program Studi Perencanaan Wilayah dan Kota dan Program Studi Arsitektur, Institut Teknologi Sumatera (ITERA).

\section{Desain dan Manajemen Ruang Kota}

Aspek keamanan lingkungan di Kota Bandar Lampung, Indoneisa, telah diatur dalam beberapa peraturan perundangan. Undang-Undang Nomor 26 Tahun 2007 tentang Penataan Ruang mengamantkan bahwa tata ruang di Indoensia bertujuan untuk mewujudukan Indonesia yang aman, nyaman, produktif, dan berkelanjutan. Di Indonesia, 
khususnya Kota Bandar Lampung, juga telah terdapat beberapa peraturan yang dapat dijadikan pedoman desain lingkungan yang aman, namun secara umum belum spesifik dan rinci dalam mengatur tata bangunan dan lingkungan yang aman bagi anak dari kejahatan. Peraturan tersebut seperti diuraikan di bawah ini.

a. Peraturan Pemerintah Republik Indonesia Nomor 34 Tahun 2006 tentang Jalan. Peraturan tersebut salah satunya mengatur mengenai jalan lingkungan. Namun, keamanan dan keselamatan yang dimaksud di peraturan tersebut masih berupa keselamatan dan keamanan secara teknis dari pengendara kendaraan yang di dalamnya terdapat pengaturan terkait kecepatan kendaraan, dimensi, dan kelengkapan jalan lingkungan. Pengaturan tersebut belum terkait pengaturan ruang jalan lingkungan yang secara operasional untuk panduan pembangunan jalan lingkungan yang aman dari suatu tindak kejahatan yang bisa terjadi di jalan lingkungan.

b. SNI 03-1733-2004 tentang tata cara perencanaan lingkungan perumahan di perkotaan. Menurut peraturan tersebut, penyediaan sarana lingkungan dan perencanaan bangunan-bangunan harus memperhatikan persyaratan keamanan, keselamatan, kesehatan dan kenyamanan bagi penghuni dan/atau pemakainya, dengan mengacu pada standar-standar terkait tata lingkungan dan bangunan. Namun, standar-standar yang dimaksud dalam peraturan tersebut lebih banyak berisi standar-standaryang terkait kemanan bangunan dari bencana, kebakaran dan konstruksi. Ada beberapa bagian standar terkait kemanan dari kejahatan. Pada peraturan tersebut terdapat arahan aspek keamanan bagi masyarakat di lingkungan sekitar dengan mengarahkan adanya fasilitas pos keamanan dan jalur pejalan kaki yang harus aman bagi pejalan kaki dari tindak kriminal. Namun, di dalam peraturan tersebut belum secara operasional mengatur atau mencontohkan secara rinci seperti apa desain jalur pejalan kaki yang aman dari tindak kejahatan dan seperti apa pengaturan sebaran pos keamanan secara rinci. Gambaran arahan desain jalan lingkungan yang disajikan dalam peraturan tersebut masih sangat umum, belum secara spesifik mengatur desain jaringan jalan lingkungan yang mempertimbangkan aspek keselamatan penggunanya dari bahaya kejahatan (Gambar 1).

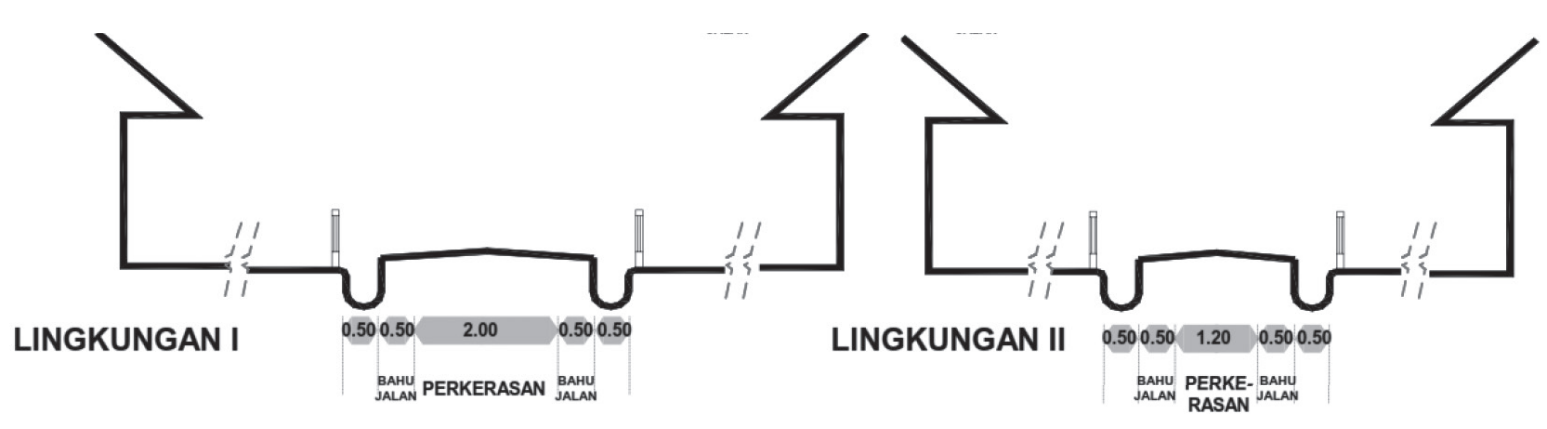

Sumber: SNI 03-1733-2004

c. Peraturan Menteri Pekerjaan Umum Nomor 06/PRT/M/2007 tentang Pedoman Umum Rencana Tata Bangunan dan Lingkungan. Peraturan tersebut di dalamnya terdapat aturan-aturan terkait keamanan lingkungan. Peraturan tersebut membeikan arahan secara normatif yang mengharuskan penetapan sistem yang dapat mencapai kualitas lingkungan kota yang layak huni baik dari segi keamanan, 
keselamatan maupun kesehatan (higienitas), sekaligus dapat mendorong penciptaan kualitas hidup dan kenyamanan warga. Peraturan tersebut juga menyatakan bahwa perlu adanya koordinasi layanan keamanan dan keselamatan. Berdasarkan ulasan yang dilakukan, peraturan tersebut belum mengatur aspek keamanan dari kejahatan di lingkungan. Namun, peraturan tersebut belum berisi contoh gambaran arahan desain lingkungan yang mempertimbangkan aspek keselamatan penggunanya dari bahaya kejahatan.

d. Peraturan Menteri Pekerjaan Umum Nomor 05/PRT/M/2008 tentang Pedoman Penyediaan Dan Pemanfaatan Ruang Terbuka Hijau (RTH) di Kawasan Perkotaan. Peraturan tersebut belum mengatur aspek keselamatan pengguna RTH dari tindak kejahatan.

e. Peraturan Menteri Pekerjaan Umum Nomor 12/PRT/M/2009 tentang Pedoman Penyediaan dan Pemanfaatan Ruang Terbuka Non Hijau (RTNH) di Wilayah Kota Atau Kawasan Perkotaan. Peraturan ini sudah berusaha mengarusutamakan aspek keamanan dari kejahatan dalam arahan desain RTNH. Namun, peraturan tersebut masih terbatas pada area parkir dengan mengarahkan penyediaan CCTV dan lampu penerangan pada area parkir. Selain itu, pearturan tersebut belum dilengkapi dengan uraian contoh gambar desainnya yang dapat dijadikan rujukan untuk pembangunan RTNH yang aman dari tindak kejahatan.

f. Peraturan Daerah Kota Bandar Lampung Nomor 10 Tahun 2011 tentang Rencana Tata Ruang Wilayah (RTRW) Kota Bandar Lampung dan Peraturan Daerah Kota Bandar Lampung Nomor 7 Tahun 2014 tentang Bangunan Gedung. RTRW Kota Bandar Lampung secara normatif menyatakan bahwa tujuan penataan ruang di Kota Bandar Lampung adalah mewujudkan Kota Bandar Lampung sebagai kota perdagangan dan jasa yang aman, nyaman, dan berkelanjutan dengan memperhatikan kelestarian lingkungan alami dan keanekaragaman hayati serta keserasian fungsi pelayanan lokal, regional dan nasional. Namun demikian, Kota Bandar Lampung belum memiliki peraturan daerah tentang Rencana Detil Tata Ruang (RDTR) dan Rencana Tata Bangunan Lingkungan (RTBL) yang merupakan alat operasionalisasi dari RTRW Kota Bandar Lampung pada skala kawasan dan lingkungan.

g. Peraturan Daerah Nomor 7 Tahun 2014 tentang Bangunan Gedung. Persyaratan Keselamatan Bangunan Gedung hanya mengatur aspek keamanan yang berkaitan dengan persyaratan kemampuan bangunan gedung terhadap beban muatan, bahaya kebakaran, dan bahaya petir. Dengan kata lain, Kota Bandar Lampung belum memiliki aturan khusus untuk pedoman desain tata lingkungan yang mengatur keamanan lingkungan dari ancaman kejahatan, terutama kejahatan terhadap anak.

Fakta tersebut juga didukung oleh penilaian ahli tata bangunan dan lingkungan di kota Bandar Lampung yang menyatakan bahwa belum ada aturan tata bangunan dan lingkungan yang fokus pada keamanan anak.

Sejauh pengalaman saya berpraktik sebagai ahli tata bangunan dan lingkungan selama sekitar 15 tahun, saya belum menemukan peraturan atau standar tata bangunan yang fokus mempertimbangkan aspek keamanan anak dari tindak kejahatan, belum ada contoh desain model fisik bangunan dan lingkungannya. (Hasil wawancara dengan salah satu ahli tata bangunan dan lingkungan di Kota Bandar Lampung).

\section{Penggunaan Teknologi untuk Pencegahan Tindak Potensi Kriminal}

Alat pelacak GPS dan CCTV sudah berkembang di Indonesia, termasuk di Kota Bandar Lampung. Teknologi tersebut semakin hari semakin terjangkau oleh masyarakat. Teknologi tersebut dipasarkan dan mudah didapatkan di pusat-pusat elektronik di Kota Bandar Lampung, bahkan toko elektronik kecil di pinggiran Kota Bandar Lampung juga 
menjualnya. Untuk pemasangan lima unit paket CCTV di Kota Bandar Lampung dengan biaya sekitar Rp 5 juta. Namun, penggunaan CCTV mulai digunakan di beberapa rumahrumah tipe besar, minimarket dan beberapa persimpangan lalu lintas.

Ada 15 titik persimpangan yang dipasang CCTV antara lain Simpang Pramuka, Simpang Unila, Simpang Sultan Agung, Simpang Urip Sumoharjo, Simpang Terminal Raja Basa, Simpang Rumah Sakit Abdoel Moelok, Simpang Kota Raja/Tugu Juang, Simpang Basuki Rahmat, Simpang Kantor Gubernur, Soekarno Hatta Pusat, Soekarno Hatta Pusat (Untung Suropati), Simpang Soekarno Hatta Pusat (Urip Sumoharjo), Soekarno Hatta Pusat (Jalan Yakudu), Simpang Soekarno Hatta Pusat (Jalan Sutami), Simpang Soekarno Hatta Pusat (Teluk Ambon). (Hasil wawancara dengan pejabat di Dinas Perhubungan Kota Bandar Lampung, 2016).

Sementara itu, sekolah belum menggunakan teknologi CCTV untuk keamanan lingkungannya. Kalaupun ada, penggunaan tersebut bukan untuk keamanan lingkungan sekolah melainkan untuk mengawas ujian nasional agar siswa tidak mencontek saat ujian. Dalam standar pelayanan pendidikan oleh sekolah, fasilitas CCTV di sekolah belum masuk di dalam penilaian akreditasi sekolah.

Demikian halnya teknologi GPS, sudah digunakan di beberapa keperluan masyarakat di Kota Bandar Lampung, seperti alat navigasi dan pelacak di mobil dan alat pelacak sepeda motor, tetapi belum begitu terbiasa digunakan untuk dipasang di anak sekolah untuk melacak anak sekolah. Di Kota Bandar Lampung sebenarnya sudah dipasarkan GPS Jam Tangan seharga sekitar 1 juta rupiah yang dapat digunakan untuk melacak anak-anak. Ada orang tua yang mau memasang GPS Jam Tangan untuk melacak anaknya, belum ada fasilitasi dari pemerintah kota maupun dari pihak sekolah.

Saya pernah lihat ada teknologi GPS Jam Tangan di internet, tetapi sekolah kami belum ada sosialisasi kepada orang tua anak didik mengenai penggunaan GPS tersebut. (Wawancara dengan guru salah satu sekolah di Kota Bandar Lampung).
Sementara itu, bel emergensi dan menara komunikasi emergensi juga belum disediakan padahal teknologi tersebut merupakan teknologi lama dan murah, mudah dipasang dan digunakan di sekolah, lingkungan perumahan, dan ruang publik lainnya. Dengan kata lain, teknologi-teknologi tersebut belum digunakan untuk keamanan lingkungan di Kota Bandar Lampung. Namun demikian, sesungguhnya perkembangan teknologi semakin maju, murah dan terjangkau, dan penguasaan teknologi masyarakat yang semakin berkembang, maka teknologi tersebut sangat potensial diterapkan di Kota Bandar Lampung.

\section{Peningkatan Aksi Komunitas untuk Pencegahan Potensi Tindak Kriminal}

Patroli keamanan di Kota Bandar Lampung masih mengandalkan patroli dari pihak kepolisian. Jika pun ada, adalah pihak keamanan (security) di lingkunganlingkungan perumahan dan sekolah yang bersiaga di posnya saja, tetapi tidak melakukan patroli. Pemerintah Kota Bandar Lampung melalui Dinas Pendidikan belum ada upaya membangun komunitas untuk keselamatan anak di lingkungan. Di Kota Bandar Lampung, memiliki ikatan orang tua di sekolah. Namun, ikatan orang tua tersebut belum dilibatkan dalam aksi patrol lingkungan. Ikatan orang tua murid tersebut hanya diberi informasiinformasi terkait kewaspadaan keselamatan anak oleh pihak sekolah. Berdasarkan pengamatan, terdapat pihak-pihak di Kota Bandar Lampung berpotensi dilibatkan dalam patroli keselamatan lingkungan yaitu pegawai Dinas Perhubungan yang bertugas di terminal, stasiun dan jalan raya, pegawai Dinas Kebersihan dan Pertamanan yang bekerja membersihkan lingkungan jalan dan taman kota, pegawai Dinas Pengelolaan Pasar yang bertugas di sekitar pasar, pegawai PT KAI di stasiun, dan petugas keamanan lingkungan swadaya (hansip atau satpam) dalam sistem keamanan lingkungan (siskamling).

Terkait pendidikan keselamatan diri pada anak, sekolah-sekolah di Kota Bandar Lampung sudah memasukkan materi keselamatan diri di sekolah, namun baru 
terbatas menginformasikan belum secara rinci operasional mensimulasikan dalam suatu pelatihan dan belum ada fasilitas di lapangan seperti jaringan rumah emergensi (Rumah Kododmo), bel emergensi, dan menara komunikasi emergensi seperti di Kota Tokyo, Jepang. Fasilitas di lapangan hanya berupa pos-pos keamanan di lingkungan sekolah, perumahan dan ruang publik lainnya serta pos-pos polisi di persimpangan jalan raya dan kantor polisi. Selain itu, terdapat call center polisi 110 untuk laporan kejahatan dan ada tempat pengaduan pasca kejadian seperti yang dilayani oleh Lembaga Swadaya Masyarakat (LSM) TeSA 129 yang melayani advokasi, rujukan, dan konsultasi masalah kejahatan terhadap anak. Fasilitas-fasilitas tersebut tentu saja membutuhkan waktu relatif lama dan jauh dari jangkauan anak-anak dan masyarakat, sehingga respon yang lambat. Berbeda kondisinya jika ada rumah emergensi (seperti jaringan rumah Kodomo di Tokyo, Jepang) di lingkungan sekitar yang bisa mudah diakses cepat atau ada bel emergensi yang juga bisa diakses cepat oleh anak-anak yang terancan atau menjadi korban kejahatan, khususnya kejahatan seksual, sehingga respon pencegahan dan penanganan bisa berlangsung cepat pula.

\section{SIMPULAN}

Kota Bandar Lampung belum menerapkan tata lingkungan perkotaan untuk keselamatan anak dari kejahatan, khususnya kejahatan seksual. Padahal, di kota di negara lain seperti di Jepang, tata lingkungan dapat menjadi solusi mencegah kejahatan terhadap anak. Penanganan kejahatan anak di Kota Bandar Lampung masih bersifat reaktif menanggulangi kasus kejahatan, belum bersifat mencegah dengan menata lingkungan perumahan, sekolah, dan ruang publik lainnya secara terencana dan terkelola dengan baik oleh pemerintah kota dengan melibatkan masyarakat di sekitarnya. Pendidikan masih sebatas menginformasikan mengenai potensi kejahatan terhadap anak terutama kejahatan seksual, namun belum sampai secara operasional melakukan pelatihan menggunakan alat-alat pendukung seperti bel emergensi dan tempat-tempat emergensi yang menyediakan bantuan penanggulangan dan pencegahan kasus. Selain itu, belum ada upaya fasilitasi pemerintah membangun keterlibatan aksi komunitas di dalam ikut berpatroli lingkungan dan mau menjadi rumah hunian emergensi sementara bagi tempat berlindungnya anak dari kejahatan.

Dengan adanya ancaman kejahatan terhadap anak, para perencana kota harus kreatif menata lingkungan perumahan, taman bermain, sekolah serta ruang publik lainnya yang aman bagi anak dari kejahatan karena saat ini peraturan pedoman dan standar dari pemerintah belum rinci dapat dioperasionalkan dalam mendesain tata lingkungan. Peraturan terkait pedoman tata lingkungan harus direvisi dengan mengarusutamakan keamanan untuk anak dari bahaya kejahatan. Dalam peraturan pedoman terkait tata bangunan dan lingkungan yang berlaku di Indonesia, khususnya di Kota Bandar Lampung, secara normatif sudah mengamanatkan pentingnya keamanan. Namun, peraturan yang ada tersebut belum spesifik fokus pada kemanan anak dari kejahatan dan belum secara rinci operasional atau contoh desainnya belum digambarkan dalam pedoman tersebut. Penelitian ini juga merekomendasikan agar adanya patroli polisi yang bersirkulasi di lingkungan perumahan, sekolah, dan ruang publik lainnya baik siang maupun malam. Selain itu, masyarakat seperti orang tua, masyarakat sekitar lingkungan, dan petugas pemerintah kota seperti di terminal, pasar, dan stasiun perlu dilibatkan dalam patroli dan dalam proses penataan lingkungan. Upaya-upaya untuk membangkitkan kembali kepedulian masyarakat sekitar perlu dilakukan seperti konsep siskamling (sistem keamanan lingkungan) dan dapat pula diupayakan pengembangan komunitas dengan membentuk jaringan relawan rumah bantuan emergensi penanganan kasus yang dapat dijadikan hunian emergensi bagi anak jika mendapatkan ancaman bahaya kejahatan dari lingkungan sekitarnya. Dalam hal pemanfaatan teknologi yang semakin maju dan terjangkau, seperti teknologi CCTV, bel emergensi dan GPS, pemerintah kota dan 
pihak sekolah harus dapat menyediakan dan memfasilitasi penggunaannya. Dengan begitu, pendidikan keselamatan diri bagi anak dapat dilakukan dengan metode pelatihan dengan cara memanfaatkan teknologi-teknologi tersebut. Penelitian ini merekomendasikan bahwa kerangka konsep seperti intervensi sosial, ekologi pembangunan, dan tata lingkungan merupakan agenda yang masih banyak kesempatan untuk dikembangkan lebih lanjut di dalam meneliti penanganan kejahatan terhadap anak, khususnya seksual terhadap anak. Beberapa topik spesifik yang direkomendasikan untuk diteliti lebih lanjut antara lain penelitian tindak (research action) peningkatan kapasitas komunitas dalam pencegahan kejahatan seksual terhadap anak dan penelitian tentang desain model fisik bangunan, ruang-ruang publik, dan lingkungan dengan mengarusutamakan keamanan bagi anak dari kejahatan, khususnya kejahatan seksual.

\section{UCAPAN TERIMA KASIH}

Artikel ini merupakan bagian dari penelitian yang didukung oleh Institut Teknologi Sumatera (ITERA). Terima kasih kami ucapkan kepada rekan-rekan yang membantu dalam pengumpulan data dan diskusi, khususnya Dr. Citra Persada Koordinator Program Studi Perencanaan Wilayah dan Kota, ITERA dan Anggi Mardiyanto, S.T., M.T. Dosen Program Studi Arsitektur, ITERA.

\section{DAFTAR PUSTAKA}

APA. 2013. Guidelines For Psychological Evaluations In Child Protection Matters. Journal of American Psychological Association 68 (1): 20 -31.

Carver, A., A. Timperio, D. Crawford. 2008. Playing It Safe: The Influence of Neighbourhood Safety on Children's Physical Activity-A Review. Health E Place 14: 217-227.

Creswell, J.W. 2007. Qualitative Inquiry and Research Design: Choosing Among Five
Approaches. $2^{\text {nd }}$ ed. Sage Publication. California.

Creswell, J.W. 2010. Reseacrh Design: Qualitative, Quantitative, and Mixed Methods Approaches. $3^{\text {rd }}$ ed. Sage Publication. California.

Daro, D. A., dan K. P. McCurdy. 2007. Interventions to Prevent Child Maltreatment. Dalam Handbook of Injury and Violence Prevention. Editor L. S. Doll, S. E. Bonzo, D. A. Sleet, J. A. Mercy. Springer. USA.

Drianda, R. P., I. Kinoshita, dan F. Deviana. 2015. Perencanaan Lingkungan Perkotaan yang Aman dari Ancaman Kriminalitas Terhadap Anak: Sebuah Studi Kasus dari Negeri Jepang. Jurnal Perencanaan Wilayah dan Kota 26 (1): 7-17.

Earls, F. dan J. McGuire. 1994. Evaluating a Community Intervention to Reduce The Risk of Child Abuse: Methodological Strategies in Conducting Neighborhood Surveys. Child Abuse \& Neglect 18 (5): 473485.

Finkelhor, D., H. Turner, R. Ormrod dan S. L. Hamby. 2009. Violence, Abuse, Crime Exposure in a National Sample of Children and Youth. Pediatrics 124 (5); 1411-1423.

Hay, T dan L. Jones. 1994. Societal Interventions to Prevent Child Abuse And Neglect. Child Welfare 73 (5): 379-403.

Jenny, C., T. A. Roesler dan K. L. Poyer. 1994. Are Children at Risk for Sexual Abuse by Homosexuals? Pediatrics 94: 41-44.

Lalor, K. 2004. Child Sexual Abuse in SubSaharan Africa: a Literature Review. Child Abuse and Neglect 28: 439-460.

Loebach, J. dan J. Gilliland. 2010. ChildLed Tours to Uncover Children's Perceptionsand UseofNeighborhood 
Environments. Children, Youth and Environments 20(1): 52-90.

Lembaga Advokasi Anak LAdA-Damar. 2016. Data Peristiwa Kejahatan di Provinsi Lampung. Lembaga Advokasi Anak LAdA-Damar. Kota Bandar Lampung.

Mulroy, E. A. 1997. Building a Neighborhood Network: Interorganizational Collaboration to Prevent Child Abuse and Neglect. Social Work 42 (3): 255-264.

Mulroy, E. A. dan Shay, S. 1997. Nonprofit Organizations and Innovation: A Model of Neighborhood-Based Collaboration to Prevent Child Maltreatment 42 (5): 515-524.

Peraturan Daerah Kota Bandar Lampung Nomor 10 Tahun 2011 Rencana Tata Ruang Wilayah (RTRW) Kota Bandar Lampung. Lembaran Pemerintah Daerah Kota Bandar Lampung Tahun 2011. Bandar Lampung.

Peraturan Daerah Kota Bandar Lampung Nomor 7 Tahun 2014 Bangunan Gedung. Lembaran Pemerintah Daerah Kota Bandar Lampung Tahun 2014. Bandar Lampung.

Peraturan Menteri Pekerjaan Umum Nomor 20/PRT/M/2011 Pedoman Penyusunan Rencana Detail Tata Ruang dan Peraturan Zonasi Kabupaten/Kota. Kementerian Pekerjaan Umum. Jakarta.

Peraturan Menteri Pekerjaan Umum Nomor 06/PRT/M/2007 Pedoman Umum Rencana Tata Bangunan dan Lingkungan. Kementerian Pekerjaan Umum. Jakarta.

Peraturan Menteri Pekerjaan Umum Nomor 05/PRT/M/2008 Pedoman Penyediaan dan Pemanfaatan Ruang Terbuka Hijau Di Kawasan Perkotaan. Kementerian Pekerjaan Umum. Jakarta.

Peraturan Menteri Pekerjaan Umum Nomor 12/PRT/M/2009 Pedoman Penyediaan Dan Pemanfaatan Ruang
Terbuka Non Hijau Di Wilayah Kota Atau Kawasan Perkotaan. Kementerian Pekerjaan Umum. Jakarta.

Peraturan Pemerintah Republik Indonesia Nomor 34 Tahun 2006 Jalan. Lembaran Pemerintah Republik Indonesia Tahun 2006. Jakarta.

Pusat Data dan Informasi Komisi Nasional Perlindungan Anak. 2015. Data Kasus Pelanggaran Hak Anak. Komisi Nasional Perlindungan Anak. Jakarta.

Rohe, W.M. 2009. From Local to Global: One Hundred Years of Neighborhood Planning. Journal of The American Planning Association 75 (2): 209-230.

Renk, K., L. Liljequist., dan A. Steinberg, G. Bosco, dan V. Phares. 2002. Prevention of Child Sexual Abuse: Are We Doing Enough? Trauma, Violence, \& Abuse 3 (1):68-84.

Sabol, W. J., C. J. Coulton., dan J. E. Korbin. 2004. Building Community Capacity for Violence Prevention. Journal of Interpersonal Violence 19 (3):322-340.

Sampson, R.J., S. W. Raudenbush, dan F. Earls. 1997. Neighborhoods and Violent Crime: A Multilevel Study of Collective Efficacy. Science. 277: 918924.

Suharto, E. 2015. Kekerasan Terhadap Anak Respon Pekerjaan Sosial. Jurnal Kawistara 5 (1):47-56.

Sulaiman, A.I., D.P.Lubis, D. Susanto, dan N. Purnaningsih. 2016. Merancang Media Informasi Dalam Musyawarah Perencanaan Pembangunan Kota Banjar Provinsi Jawa Barat. Jurnal Kawistara, 6 (1): 93-106.

Tallo, A.J., dan D.A Paramita. 2015. Identifikasi Tingkat Partisipasi Masyarakat Studi Kasus Kampung Lorotan, Kelurahan Kotalama, Kota Malang. Jurnal Kawistara 5 (3): 275286.

Undang-Undang Nomor 26 Tahun 2007 Tentang Penataan Ruang. Lembaran 
Pemerintah Republik Indonesia Tahun 2007. Jakarta.

UN HABITAT. 2016. New Urban Agenda. UN HABTITAT. USA.

Widiyanto, D. Dan R. Rijanta. 2012. Lingkungan Kota Layak Anak (ChildFriendly City) Berdasarkan Persepsi Orangtua di Kota Yogyakarta. Jurnal Bumi Lestari 12 (2): 211-216.
Yin, R.K. 2009. Case Study Research: Design and Methods. $4^{\text {th }}$ ed. Sage Publication. London.

Yunianto, A.D., S.R.P. Sitorus, dan K. Munibah. 2016. Analisis dan Arahan Pengembangan Ruang Terbuka Hijau Dalam Mendukung Green City Kota Ungaran Kabupaten Semarang. Jurnal Kawistara 6 (1): 1-9 